\title{
Effective Waste Management and Environmental Control
}

\author{
${ }^{1}$ Engr. Sangotola T.M, ${ }^{2}$ Ladipo O.A, ${ }^{3}$ Adeyeye A.H. \\ Department of Civil, Mechanical, Electrical/Electronic Engineering. \\ The Polytechnic Ibadan, Adeseun Ogundoyin Campus, Eruwa.
}

\begin{abstract}
There is wide spread interest in the world today in the methods that enable the re-use of waste. According to Webster's Mew Practical Dictionary, 'Waste' means "Thrown away as worthless after being used. i.e. of no further use to a person, animal or plant; contrary to this opinion, it has been discovered that what is regarded as waste or worthless, when worked upon can be manipulated to generated or produce materials that are beneficial for the use of man.

This paper throw light into how waste resources can be control by analysis the theories of waste management, recycling, re-use disposal and compositing from organic wastes and ways by which farm and municipal waste can be worked upon to produce materials that are beneficial for the use of man.
\end{abstract}

Keywords: Effective Waste Management, Environmental Control, Re-use of Waste Disposal, Waste, Recycling of waste.

\section{Study Area}

\section{Introduction}

The Ibadan North Local Government was established by the Federal Military Government in September 27, 1991. It was carved out of the defunct Ibadan Municipal Government (IMG) along with four others. The jurisdiction of Ibadan North Local Government covers the area between Beere round about to Gate, Idi-Ape to Basorun and off Lagos-Ibadan expressway, State Secretariat, University of Ibadan and Agbowo Area. Bodija market was also situated within the Ibadan North Local Government. The Local Government is bounded on all sides by one local or the other. On the North by Akinyele Local Government, on the West by Ido, Ibadan North East by Akinyele Local Government by the 2006 census, the population of Ibadan North Local Government was 152,602 males and 155,511 female. The total land area is $145,581 \mathrm{~m}^{2}$ the inhabitants of Ibadan North Local Government are predominantly Yoruba's, however, there are other ethnic group. The Urobos, Hausas, Tapas and Ilorins. The premier University of Ibadan and The Polytechnic Ibadan fall within the jurisdiction of Ibadan North Local Government. In addition, Adeoyo State Hospital and University College Hospital are also located within Local Government of Ibadan North. The administrative headquarters of Oyo is located approximately in latitude $3^{0} 58^{\prime \prime}$ East and transitional zone between the high forest and the savanna belt Nigeria.

\section{General Background}

Waste as it implies could mean many things, it could be something that is no longer needed for use. The term waste in this context as it relates to public health (sanitation) is of least dimension. It ranges from solid state to gaseous states. In reality, the end focus of it is that it constitutes nuisance to the public quarters and as such effective and efficient way of getting rid of it has to be employed.

Poor refuse disposal encourages fly breeding it promotes the transmission of feaces-oral infections; it can obstruct street and drainage channels when it is neither controlled nor collected. Waste can be in the form of solids, liquids and gases depending on the production process from which they are generated and raw materials involved instead of drawing the usual distinction which divides it into the group's solids and liquids, waste paper and sewage respectively. The organic materials which include sewages, food waste and garden waste are all subject to natural processes of purification and decomposition, hence decay rapidly. Inorganic wastes on the other hand are more stable and long life. They are remains undegradable in same position they are dumped such that materials which are of potential values can be recovered and recycled.

Layman views environment just as local surrounding where one lives. Environment is a complex and dynamic relationship between living and non living components of a particularity. Akinyele 2000 refers to environment as the biological and physical surrounding of plants, animal and human being. He further stressed that the factors which brings about complete interactions in an environment includes climate, natural and physical features, air, water, landforms, soils, topography and cloud-cooler. All these sustain the existence of all living beings. Therefore, environment is a huge pool of resources comprising of the earth's landscape (lithosphere), the water (hydrosphere) and the mineral matter (including oil, water and gas) man being conscious of these values of effective waste management and environmental control. 
The timber and non-timber agro forestry products descents heavily on them for the survival, hence Adekoya 2000 observed that the survival of the people is often dependent on the resources provided through the effective waste management and control for exploitation and there is usually a concern for sustainability within units of economics survival and environmental control awareness.

\section{Objective And Methology}

The objective of the research work is to bring out ways to obtaining the advantages of effective management and environmental control. To achieve these objectives the following procedure are followed:

- Research on effective managements and ways of environmental control.

- Research on composition and other quantities volume percentage of household waste in the town (Ibadan) to know the percentage which can be re-used.

- Visiting the Oyo State Waste Management Authority to know how the waste is presently managed in the city (Ibadan).

\section{GASEOUS WASTE}

Gaseous compounds are dangerous to human health they form gaseous pollutants produced from the activity of man gaseous waste include smoke and the table below.

\begin{tabular}{|l|l|}
\hline Gaseous waste & Sources \\
\hline Carbon monoxide (co) & $\begin{array}{l}\text { Products of human respiration from exhaust pipe of automobile, industrial } \\
\text { machines, generators, etc. } \\
\text { Dust }\end{array}$ \\
Smoke & $\begin{array}{l}\text { Fesult of human activities on soil, it is also affected by the present condition. } \\
\text { From motor instead construction of gutter out while open refuses building. }\end{array}$ \\
\hline
\end{tabular}

\section{SOLID WASTES GENERATION}

Waste excretion is when materials become valueless for the owner and they discarded. The rate at which this occurs is a determinant of how much waste is generated by the person; usually it is measured in the basis of by capital (i.e. person) or households per day. In 1985 the Federal Ministry of Housing and Environment determined solid waste generation rated in Nigeria urban centers and galley the following figures for the Ibadan per capital $-0.39 \mathrm{~kg}$ per day.

Also unadjusted total annual volume of solid waste generated per year was derived as shown below. 1982:350,823 tons per year 1985:382,224 tons per year 1990:440,956 tons per year 2000:559,882 tons per year

This data highly outdated and needs to be up dated. However, it gives a good picture of the values of solid waste generated per year in the city of Ibadan which is quite enormous. Hence, there is need to have a proper system of managing and control the waste effectively.

\begin{tabular}{|c|c|c|c|c|c|c|c|}
\hline \multirow[t]{2}{*}{ COMPONEN' } & \multicolumn{7}{|c|}{ MEAN PERCENTAGE COMPOSITION BY WEIGTH } \\
\hline & G.R.A & Bodija & $\begin{array}{l}\text { Private layout } \\
\text { (Mokola \& } \\
\text { Sango) }\end{array}$ & $\begin{array}{l}\text { Priva } \\
\text { (Oke }\end{array}$ & & Agugu & $\begin{array}{l}\text { Traditiona } \\
\text { 1 Market } \\
\text { (Oja Oba) }\end{array}$ \\
\hline Leaves & 7.5 & 4.3 & 11.2 & 14.0 & 50.1 & 18.7 & 5 \\
\hline Food remains & 19.2 & 9.1 & 3.6 & 6. & 6.9 & & \\
\hline Paper & 15.1 & 26.2 & 10.7 & 19.4 & 15.2 & 16.6 & \\
\hline Rags & 1.3 & 1.5 & 4.2 & 6.8 & 4.5 & 10.9 & \\
\hline Plastic \& & 4.1 & 8.9 & 3.7 & 11.6 & 4.8 & 6.1 & \\
\hline Tins \& Metals & 20.8 & 11.4 & 20.1 & 16.4 & 7.7 & 12.8 & \\
\hline $\begin{array}{l}\text { Bottles \& } \\
\text { Glasses }\end{array}$ & 9.9 & 11.8 & 12.7 & 9.0 & 6.1 & 6.0 & \\
\hline $\begin{array}{l}\text { Ash, Dust \& } \\
\text { Stones }\end{array}$ & 5.9 & 16.7 & 28.3 & 19.1 & 29.8 & 12.0 & \\
\hline Hospital & 10.7 & 15.8 & 14.5 & 13.8 & 20.1 & 17.7 & \\
\hline Sewage & 6.9 & 12.9 & 15.7 & 16.6 & 18.5 & 21.2 & \\
\hline Slug & 13.3 & 14.2 & 8.8 & 17.2 & 23.4 & 20.3 & \\
\hline
\end{tabular}




\section{Solid Waste Management}

Solid waste management can be defined as the effort associated with the control of generation, storage, collection, transfer and transport, processing and disposal of solid wastes in a manner that is in accord with the best principles of public health, economics, engineering, conservation, aesthetic and others environmental considerations which are responsive to public attitudes.

From the above definition, it can be summarized that there are various stages in solid waste management, namely:

Generation: This is stage where solid wastes are produced from the various households, institutions, industries and the commercial centers.

Storage: This is a stage where generated wastes are kept before they are collected. This involves the use of household bins, waste storage areas in factories, communal storage points, particularly in markets and schools and so on.

Collection: There are two phases under this storage, namely: primary and secondary collection. Primary collection is the first stage of collection between the waste generation and secondary storage. Sometimes this directly transported after primary collection. It is common knowledge to see hand drawn carts, especially in Lagos, collecting waste from households and markets stalls to a central point for subsequent transport to disposal. In some areas in Ibadan, particularly, the government reservation areas, wastes are collected by designated contractors who transport them directly to disposal. On the other hand, secondary collection or transportation entails collection of waste brought to a centrally designated point, usually refer to as transfer station, for onward transportation to the disposal sites. This is usually vehicular in cities, but in some small towns in developing countries animal or human drawn carts are used. This stage is most common in large urban areas. For example: Lagos where the distance to disposal sites are far.

Disposal: This is the final destination of the waste. It may be a land fill, in cinema or a composed plant and so on.

\section{The Good Practice}

In the considering the best practice for solid waste management in order to achieve sustainability, particularly at a community level, the four waste-related area to be considered. These areas are interrelated and mutually supportive. However, the main emphasis to be given to each area will be varied according to the local socio-economy and physical conditions of the town or city the rate of generation and composition of the wastes. In a nut shell, the four rate related areas of focus in solid waste management are:

- Minimization.

- $\quad$ Maximizing environmentally sound waste re-use and recycling processes.

- $\quad$ Promoting environmentally sound waste disposal treatment.

- $\quad$ Extending waste service coverage.

In minimizing wastes, the major objective includes:

1. Stabilization or reduction of the production of wastes destined for final disposal;

2. Strengthening of procedures for accessing waste quality and composition changes.

Also maximizing environmentally sound waste re-use and recycling programme recognizes nature of the economics of waste disposal. Waste and recycling, resource recovering is increasingly becoming the costeffective approaches to control waste. Waste recycling is one of the ways to go if our society is to achieve effective waste management and control of our waste. Boladouer (2006) take a critical look at the above composition of waste generated in Ibadan will reveal to us that not are useless. There are some of these wastes that can be converted into one form or the other for economic benefit of mankind. Developed nation of the world have come to realize that they need to find alternative way of handling wastes. This has become evident given the rapid urbanization and the alarming rate at which land is becoming depleted such that the hitherto conventional means of disposing wastes are becoming impracticable by the day. Hence the need to depart from traditional practice of cradle to grave approach waste management and embrace cradle to cradle approach.

\section{Conclusion}

The characteristic of effective waste management and environmental control changed predominantly organic matters. More than $80 \%$ in the late fifties to a more heterogeneous mature, also, the organic material still take the highest percentage, and the proportion then has been drastically reduced. The proportion of metals, glass, plastic and paper gradually increasing abandoned automobiles, refrigerators, cookers and other bulky metallic items constitute a big problem, the items are often abandoned in selected open space where they are create poor environmental condition. Collection and transportation of solid and liquid waste are not effectively carried out because of technique financially and administrative short-comings of the authorities that involved. The common disposal method is crude land-fill, composting should be carried out to recommend the desirable composting method for use at a specific location. 
The conclusion is as follows:

i. Government should have more focus/interest on waste to wealth programmes.

ii. The Oyo state government should budget sufficient money for proper funding of the OYSWMA (Oyo State Waste Management Authority) for efficient foundation.

iii. Staff of the OYSWMA should be sent abroad for training on waste management and utilization in general, professional staff should be employed.

iv. Public education on waste management is highly necessary. Hence government should promote this.

v. Purchase of dust bin by each household, shop and other commercial centers should be made compulsory.

vi. There should be sanitary inspectors who would monitor people around and fine anyone who disobey environmental cleaning rules e.g. anyone who litter the surrounding carelessly by throwing off papers, nylon, etc anywhere or dispose his/her households waste in any unapproved place.

\section{Recommendation}

Government should have more focus on this topic "effective waste management and environmental control" deduce every means through which positive things could be generated from waste resources, give more encouragement to waste to wealth programmes, establish some industries and plants like the composting plant for conversion of biodegradable waste to various, re-usable energy form, soil conditioner, etc. recycling plant for recycling non-biodegradable matters into the waste components.

It is also recommended that the project should be made available to people freely. Especially to appropriate government quarters to serve as eye opener on the topic "effective waste management and environmental control". Knowledge on what solid waste management means and ways by which waste resources can be regain and re-utilized, it should also be made available freely to the Oyo State Solid Waste Management Board.

\section{References}

Adekoya B.T. (2000) Solid Waste Management. Published by Concord Press Ogun State. Pg. 15-20.

[1]. Akingbile L.A. (2000) Environmental Extension as Effective Tools for Sustainable Natural Resources "JOURNAL OF ENVIRONMENTAL EXTENSION vol.1-No 1 Pg. 69-74.

[2]. Bola Olowe, (2006) Sustainability Community Base. Solid Waste Management Projects paper delivered at the national conference of the environmental division. The Nigeria Society of Engineers, Ibadan Branch Pg. 4-6.

[3]. Chongrak-Polpra set (1996) Organic Waste. Recycling Technology and Management Second Editing Pg 69-108, 115-162.

[4]. Conared PSTRUAUB. (2005) Practical Handbook of Environmental Control Pg. 375-453.

[5]. Fanida A. (1997), Introduction to Effective Solid Waste Management Engineering Control. Bibis Press, Ibadan. Pg. 25-30.

[6]. Madumere A.J. (2000) Environmental Programme as in dispensable tools for enriching public environmental education in Nigeria. STAN 418f Annual conference proceeding. Pg. 188-190.

[7]. Sangotola T.M. (1997) Solid Waste Management Paper Slated for Publication of Faculty of Engineering Journal (2007). Pg. 3-10 Vol. 4

[8]. Scridhar M.K.C. (2003) Nature of Solid Wastes and their Management. A paper presented at a one day seminar organized by MANNAFEFF, Ibadan. Pg. 2-3. 